\title{
ESTABLISHMENT AND SURVIVAL OF THREE INVASIVE TAXa of the Genus Reynoutria (POLYGonaceae) in MESIC MOWN MEADOWS: A FieLd EXPERIMENTAL STUdY
}

\author{
Jiři Brabec ${ }^{1)}$ \& Petr Pyšek P) $^{2}$ \\ 1) Department of Botany, Charles University, Benátská 2, CZ-128 01 Praha 2, Czech Republic; \\ fax +420221953125, E-mail brabec@naturcuni.cz
}

2) Institute of Botany, Academy of Sciences of the Czech Republic,CZ-252 43 Prühonice, Czech Republic; fax +420267750031, E-mail pysek@ibot.cas.cz

Keywords: Alien plants, Hybridization, Invasion, Grazing, Mowing, Czech Republic

\begin{abstract}
The effect of traditional management on the initial phase of invasion into mesic mown meadows was studied in the Krrivoklátsko protected landscape area in Central Bohemia, the Czech Republic. In 1996, rhizome fragments of alien species native to Asia, i. e. Reynoutria japonica, $R$. sachalinensis and their hybrid $R$. $\times$ bohemica were planted in experimental plots and their establishment recorded. Established plants were then subjected to the following six treatments which simulated the management practices traditionally used in the study area: mowing twice a year, grazing by goats and sheep separately at two different intensities, and a control plot. Plant survival was recorded in the two years following planting. In order to compare the effect of the growing period, the experiment with $R$. japonica was conducted in two subsequent years (1995 and 1996) thus allowing observations over three years on this species. The experiment was carried out in two sites (meadows), with three blocks of treatments established in each. Significantly better establishment was found in $R$. japonica and $R$. xbohemica than in $R$. sachalinensis. Survival of all three taxa was negatively effected by all the management treatments applied $(P<0.001)$. In control plots with plants of all three taxa, there was virtually no mortality during the growing seasons of either year and the number of surviving plants decreased only in the winter. In the former two species, $38.5 \pm 19.4 \%$ of plants survived the first winter, the corresponding figure for the latter being only $7.2 \pm 6.1 \%$. It can be concluded that traditional management provided it is applied continuously may represent an effective barrier against the invasion of the Reynoutria species. Once ceased, the potential for invasion increases and if invasion occurs, special control measures are required to eliminate the invading plants effectively.
\end{abstract}

\section{INTRODUCTION}

In studies devoted to biological invasion, there is a growing consensus about the importance of the recipient habitat and the necessity to take into account both its properties and the characteristics of the invading species. WILLIAMSON (1996) summarized available data and concluded that all types of communities are potentially invasible (see also CRAWLEY 1987, USHER 1988). There is quantitative evidence that some communities are more easily invaded than others (CRAWLEY 1987, PYŠEK et al. 1998). Factors affecting community invasibility have been repeatedly described, including the type, frequency, and intensity of disturbance as well as a change in its regime at the site (HoBBS 1989, HoBBS \& HuMPHRIES 1995), successional position (REJMÁNEK 1989, HoBBS \& HUENNEKE 1992, KOWARIK 1995, BASTL et al. 1997), and nutrient and moisture conditions (VITOUSEK et al. 1987, HOBBS \& HUMPHRIES 1995). 
In the Central European landscape, the distribution of alien plant species in vegetation is rather uneven. One of the vegetation types which is rarely invaded is grasslands. PYŠEK et al. (1998) have shown, based on the analysis of more than 32,000 localities of alien species in the Czech Republic, that the contribution of meadows to the total number of localities was disproportionately low. However, invasion in such habitat types does occur (PYŠEK \& PYŠEK 1995) and many invasions are located along water courses which serve as an efficient vector to transport the diaspores of invasive species (THÉBAUD \& DEBUSSCHE 1991, PYŠEK \& PRACH 1993). The species of the genus Reynoutria possess many of the features of an "ideal invader" and are considered among the most vigorous European aliens (BEERLING et al. 1995, MARIGO \& PAUTOU 1998). Plants are spread by vegetative fragments in water and thus represent a major threat to the adjacent vegetation, often valuable from the viewpoint of nature conservation.

The present study was carried out in one of the most valuable sections of the Central Bohemian landscape, the Krrivoklátsko Landscape Protected Area. The species studied represent vigorous invaders frequently found in the immediate vicinity of water courses (about $30 \%$ of their localities in the Czech Republic, PYŠEK \& PRACH 1994). However, they do not invade successfully into mown meadows of the protected area which represent an important component of the regions vegetation. Knotweed invasion into such vegetation types was observed sporadically in other parts of the country (BRABEC \& PYŠEK, unpubl. observ.). Moreover, it seems to be potentially accelerated by recent summer floods in the territory which are thought to increase the dispersal potential of water courses in terms of the spread of alien species and in particular knotweeds. However, no hard data are yet available on the subject. It can be supposed that floods, by not only bringing the knotweed propagules (fragments of rhizomes and stems) but also by covering the turf with soil, mud and other accumulated material can create natural conditions favouring the establishment of Reynoutria plants. The present paper was thus aimed at investigating the chances of potential knotweed survival in meadows adjacent to water courses over several years, and compare their survival under traditional meadow management (grazing and mowing) wherein the management was ceased and the meadows left abandoned. The Reynoutria species have the potential to establish in managed sites as documented by the fact that in Britain, Reynoutria japonica is common in pastures (BEERLING 1991, BeERLING \& PALMER 1994).

The experiment tested two alien congeners and their spontaneous hybrid, and was intended to compare the invasive potential of three taxa. Assuming that (i) there is a repeated influx of Reynoutria diaspores into the communities under question, and (ii) new plants establish easily from these diaspores (BROCK \& WADE 1992, BROCK et al. 1995), then the present study focused on answering whether these taxa are prevented from massive invasion by (i) not being able to compete with closed grass-dominated vegetation or (ii) by the traditional management of these sites. If the latter is true, the secondary aim would be to evaluate the efficiency of particular modes of management.

\section{STUDY SITES}

The study was carried out in the valley of the Brejlská strouha brook $\left(50^{\circ} 06^{\prime} \mathrm{N}, 13^{\circ} 52^{\prime} \mathrm{E}\right)$ in the region of Krrivoklát, Central Bohemia, the Czech Republic, ca. $40 \mathrm{~km} \mathrm{~W}$ of Prague, at the $365-370 \mathrm{~m}$ a.s.l. (mean annual temperature $6.9^{\circ} \mathrm{C}$, annual mean precipitation $522 \mathrm{~mm}$; data from the Lány meteorological station, 50-year average). 
The study was carried out in the Křivoklátsko Landscape Protected Area. Two floodplain meadows were chosen for the experiment in order to simulate as real a situation as possible, i.e. the potential dispersal of diaspores of Reynoutria species into meadow communities, e.g. in the case of a flood. Meadows of this kind represent some of the most valuable preserved communities in the place of unique deciduous forests at low altitudes (NEUHÄUSLOVÁ et al. 1998). The following criteria were taken into account when selecting the study sites:

(1) These meadow communities are common in the landscape of the Křivoklátsko Landscape Protected Area, i.e. they represent typical meadows of the area. Two meadows were chosen, and both belong to the alliance Alopecurion pratensis PASSARGE 1964: (i) Vegetation cover of Site I was dominated by Alopecurus pratensis L., Agrostis capillaris L., Geranium palustre L. and Arrhenatherum elatius (L.) J. PRESL et C. PRESL and its composition reflected the gradient of moisture. (ii) Site II harboured more heterogeneous vegetation, depending on the relief. In both sites, the experimental plots were located in the relatively homogeneous central part of the meadow.

(2) Knowledge of the history of natural conditions in terms of their management. Until 1985 , both meadows were regularly mown twice a year for hay (or sometimes grazed by sheep instead of the second mowing). From 1986 to 1992 there was a single mowing per year and in 1993 the mowing ceased. During the last 50 years, both sites have been regularly flooded: Site I once in five years, and Site II once in three years. Flooding occurs mostly in April and May, and rarely in June (personal communication from local inhabitants).

(3) Taxa of the genus Reynoutria occur in the region so that the geographical and/or climatic barriers that could possibly play a role in invasion are irrelevant. There are three known localities of $R$. japonica within $10 \mathrm{~km}$ of the sites, the nearest located $3 \mathrm{~km}$ from the study sites. $R$. sachalinensis also occurs $3 \mathrm{~km}$ of the sites. The distribution of $R$. xbohemica is insufficiently known (MANDÁK \& PYŠEK 1997).

\section{STUDY SPECIES}

Reynoutria japonica HoUTT. var. japonica and $R$. sachalinensis (F. SCHMIDT) NAKAI (Polygonaceae) are stout rhizomatous perennials, reaching a height of 2.5 and $4 \mathrm{~m}$, respectively, producing a large amount of biomass (HORN \& PRACH 1995, BROCK 1994) and having a large leaf area. The former species is native to Japan, Korea, Taiwan and China (see BEERLING et al. 1995 for distribution map), the latter to Sakhalin, the southern Kurile Islands and the Hokkaido and Honshu islands of Japan (TADEZOKU 1965). R. japonica was introduced to Europe as early as 1825 (SAlisbuRY 1961, JALAS \& SUOMINEN 1988, SUKOPP \& SUKOPP 1988) and later to North America (SEIGER 1997). R. sachalinensis has been known in Europe since 1863 (SUKOPP \& STARFINGER 1995). Both species were introduced into the Czech Republic in the 19th century (PYŠEK \& PRACH 1993), primarily as garden ornamentals. Since they regenerate easily from rhizomes (BROCK \& WADE 1992) and stem fragments (BROCK et al. 1995), and their distribution is to a large extent confined to the vicinity of rivers and streams, they have spread considerably, using water as a main dispersal agent (SCHWABE \& KRATOCHWIL 1991, PYŠEK \& PRACH 1993, DE WAAL et al. 1994). They are thought to be gynodioecious, i.e. producing male-sterile and hermaphrodite individuals, but male-fertile clones of $R$. japonica are not known from the Czech Republic or elsewhere from Europe where this topic was seriously investigated (BEERLING et al. 1995). All British plants of Reynoutria japonica probably represent clones originating from a single genotype (BAILEY 

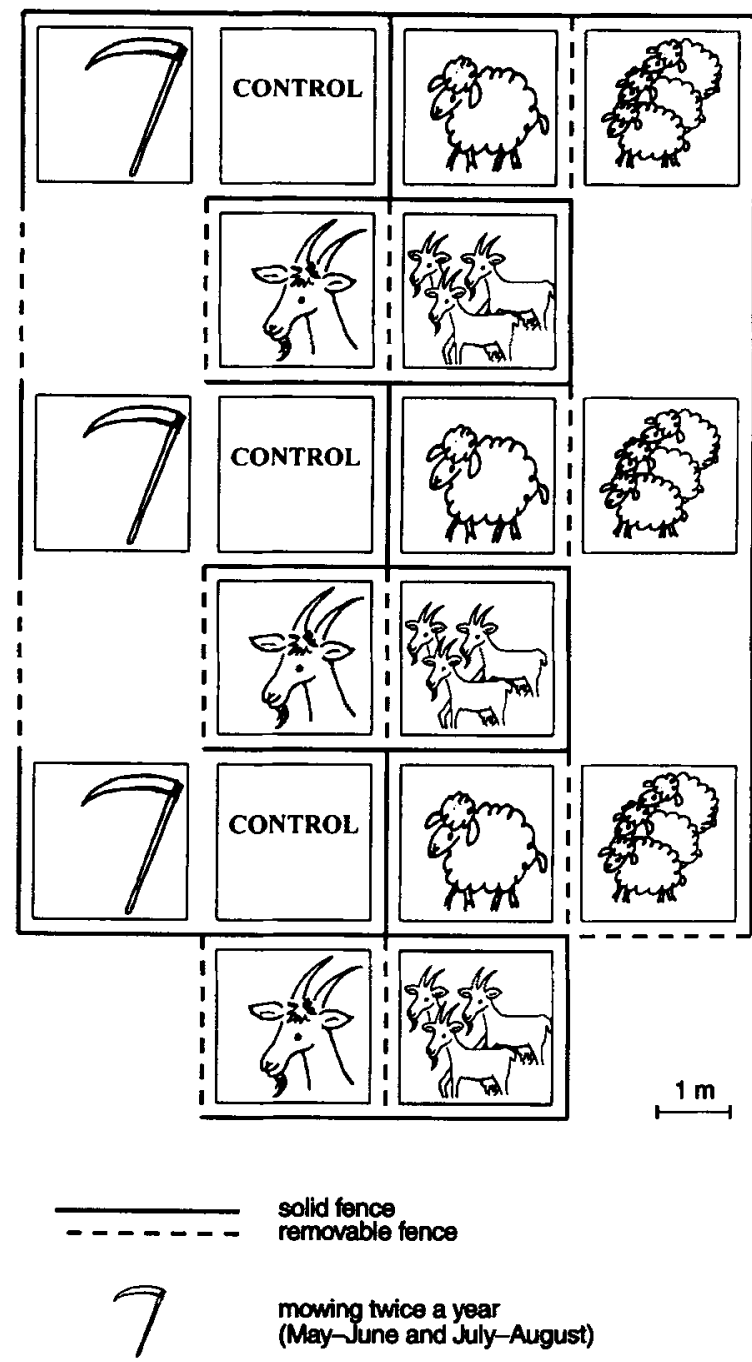

CONTROL control plot without any management

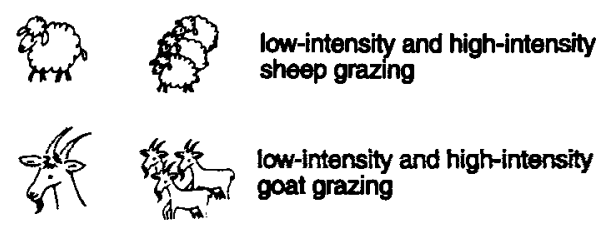

Fig. 1. Spatial arrangement of three blocks, consisting of six treatment applications each, and location of permanent and removable wooden fences. Permanent fences were used to separate plots $\left(6.25 \mathrm{~m}^{2}\right.$ each) grazed by sheep from those grazed by goats while removable fences were used to regulate the intensity of grazing. Hence, e.g. the high intensity sheep grazing was performed in the five plots on the right ( 3 experimental plus 2 transition plots, giving the total of $31.3 \mathrm{~m}^{2}$ ) while the low intensity regirne was extended by the three adjacent plots (i.e. on $50 \mathrm{~m}^{2}$ ). See Methods for the description of grazing pressure under particular treatments. The same experimental design was used in both sites (I and II). 
et al. 1995). In terms of dispersal, Reynoutria species rely heavily upon vegetative reproduction (BROCK \& WADE 1992, BROCK et al. 1995).

The hybrid of both species, Reynoutria $\times$ bohemica CHRTEK et CHRTKOVÁ has been described from the Czech Republic (CHRTEK 1990). Its distribution has not been sufficiently studied in the native or adventive distribution area of its parents. However, data from the United Kingdom (BAILEY et al. 1995) and the Czech Republic (MANDÁK \& PYŠEK 1997) suggest that it is rather common. The hybrid is gynodioecious and both hermaphrodite and male-fertile clones were reported from the UK (HOLLINGSWORTH et al. 1998), although the fecundity of hybrid plants is thought to be very low (BAILEY \& STACE 1992). Available data indicate that, at least locally, the hybrid possesses higher genetic variation than both parents and that at least some of its variation is attributable to hybrid fertility (HoLLINGSWORTH et al. 1998).

In $R$. sachalinensis, plants recorded to date have been tetraploids $(2 \mathrm{n}=44)$. All the European plants of Reynoutria japonica var. japonica recorded so far have been octoploids $(2 n=88)$. Tetraploid populations $(2 n=44)$ do occur in the area of native distribution (BAILEY 1990, BAILEY et al. 1995) but have not yet been found in the Czech Republic. The hybrid Reynoutria $\times$ bohemica has $2 \mathrm{n}=66$.

\section{METHODS}

\section{Experimental design}

Rhizomes of Reynoutria taxa were collected in Prague, about $40 \mathrm{~km}$ E from the experimental site; each taxon was represented by a single clone. Rhizomes were transported to the site, cut into segments $2.5-5 \mathrm{~cm}$ long and $0.8-1.5 \mathrm{~cm}$ in diameter, and planted immediately. Litter was scraped aside, and the segment pushed into the soil and covered with litter again. The segments were planted randomly into particular plots. Chromosome numbers were counted in samples representing each taxon and used in the experiment, revealing $2 \mathrm{n}=88$ in $R$. japonica, $2 \mathrm{n}=44$ in $R$. sachalinensis, and $2 \mathrm{n}=66$ in $R$. xbohemica.

The experimental design was based on blocks consisting of six $210 \times 210 \mathrm{~cm}$ plots, representing the six management treatments. Three blocks were established in each experimental site (Fig. 1), giving a total of 6 blocks and 36 plots. In each plot, four $60 \times 60$ $\mathrm{cm}$ subplots were established and used for planting rhizome segments. Thirty segments of each taxon were randomly selected from the sampled material and planted in three subplots (distributed evenly over the subplot area) in April 1996. In addition, $R$. japonica was planted also in April 1995 to make it possible to carry out one more year of monitoring and evaluate the effect of planting year. Each of the six treatments simulated the management regime used on the meadows of the study region in the years preceding the establishment of the experiment (see Fig. 1 for technical details).

High-intensity sheep grazing caused mechanical disturbance of turf and complete removal of aboveground vegetation. The plots were grazed 3-4 times a year for two days, on the first day there was an intensity of cca 0.1 sheep $/ \mathrm{m}^{2}$, on the second day $0.16 \mathrm{sheep} / \mathrm{m}^{2}$.

Low-intensity sheep grazing represents removal of aboveground vegetation associated with trampling. In this case, vegetation was partly grazed with no species-specific preferences and partly laid down by trampling. The plots were grazed 3-4 times a year for one day with the intensity of ca. 0.1 sheep $/ \mathrm{m}^{2}$. 
High-intensity goat grazing caused the mechanical disturbance of turf and non-selective, almost complete removal of aboveground vegetation. The plots were grazed 3-4 times a year for two days using $0.16 \mathrm{goat} / \mathrm{m}^{2}$.

Low-intensity goat grazing represents selective removal of the part of the aboveground vegetation (mostly herbs and fleshy leaves). The plots were grazed 3-4 times a year for one day with the intensity of 0.16 goat $/ \mathrm{m}^{2}$.

Mowing was carried out twice a year (May-June and July-August) and the time schedule corresponded to the management traditionally used in the region.

Control plots were left without any management.

Grazing in both Site I and II started when the vegetation (dominated mainly by Alopecurus pratensis) was $10-15 \mathrm{~cm}$ tall. To respect the grazing habit of animals, sheep were kept together (4-5 sheep and 1-2 lambs). On the first day, the animals grazed on all sheep-treated plots regardless of intensity (including transitional plots which were necessary for technical reasons, see Fig. 1); the total area of the pasture was $50 \mathrm{~m}^{2}$. On the second day, the grazing continued only in the high intensity (and transitional) plots, i.e. on the pasture of the total area $31 \mathrm{~m}^{2}$. Goats were kept separately when grazing, i.e. one adult animal or two kids in the fenced area of $6.25 \mathrm{~m}^{2}$ surrounding the experimental plot.

For technical reasons (mainly because of the feeding habit of sheep) the three blocks within each site represent partial pseudo-replicates (HURLBERT 1984 - see Fig. 1). In the study sites, moisture was considered the most important ecological factor affecting not only the composition of vegetation but also the establishment and survival of potential invaders as well as the intensity of competition. To take into account the possible effects of this factor, the soil water content was determined in each of the 18 experimental plots. Two samples were taken from $10 \mathrm{~cm}$ below the soil surface 7 times a year $(28 \mathrm{March}, 15$ April, 2 May, 18 May, 1 June, 18 June, and 20 July, 1996) and the average value was used. The obtained data on moisture were subjected to PCA (on the correlation matrix) and the position of particular plots on the first ordination axis was used as a covariate in ANCOVA in order to take the possible effect of this factor into account and reduce the influence of the experimental design with pseudo-replicates. The first PCA axis explained $68.2 \%$ of the variation in the data set.

The grazing experiment was terminated in 1998. Plants in grazed plots were killed and removed from the meadows. Mown and control plots are still being monitored for further development and attention is paid to ensure that plants do not spread from the study area. Mowing continues in respective plots up to the present.

\section{Data sampling and analysis}

The establishment and survival of Reynoutria plants was recorded for two growing seasons after the planting in April 1996: April, June, July, September 1996, April, May and July 1997. In addition, the $R$. japonica treatment planted in 1995 was subjected to additional sampling dates in April, June, July and September 1995. During each sampling date, the number of living plants (rhizome segments) was recorded. A rhizome segment bearing at least one living above-ground shoot was considered as living.

The data were analysed using an analysis of covariance (GLM approach to ANCOVA) in the SPSS 8.0 for Windows. Because the test was focused mainly upon evaluating the effect of management on established plants and the establishment rate differed among plots, the highest number of living rhizome segments (i.e. plants) recorded in the given plot in the 
Table 1. Number of established rhizome fragments of three taxa of Reynoutria as recorded 67 weeks after planting. Year of planting is shown in parentheses. Results from different years (1995 and 1996) are included for $R$. japonica. Mean $\pm \mathrm{s}$.d. is shown $(n=36)$. Number of initially planted fragments was 30 per $60 \times 60 \mathrm{~cm}$ plot. The rhizome fragments bearing at least one living shoot were considered as established.

Site

Site II

(No. of established \% (No. of established \%

fragments)

fragments)

Pooled data (I+II)

(No. of established \%

fragments)

$\begin{array}{lllllll}R . \text { japonica (1995) } & 22.3 \pm 3.8 & 74.3 \pm 12.6 & 16.0 \pm 4.0 & 53.3 \pm 13.3 & 19.1 \pm 5.0 & 63.8 \pm 16.6 \\ R . \text { japonica (1996) } & 22.6 \pm 3.7 & 75.4 \pm 12.3 & 18.6 \pm 2.7 & 61.9 \pm 9.1 & 20.6 \pm 3.8 \text { a } & 68.6 \pm 12.7 \\ R . \times \text { bohemica }(1996) & 19.6 \pm 3.9 & 65.4 \pm 13.0 & 15.7 \pm 3.9 & 52.2 \pm 13.1 & 17.6 \pm 4.4 \mathrm{a} & 58.8 \pm 14.5 \\ R . \text { sachalinensis }(1996) & 13.2 \pm 4.5 & 43.9 \pm 15.1 & 8.3 \pm 4.0 & 27.8 \pm 13.3 & 10.8 \pm 4.9 \mathrm{~b} & 35.8 \pm 16.2 \\ \text { Pooled } & 19.4 \pm 5.5 & 64.7 \pm 18.2 & 14.6 \pm 5.3 & 48.8 \pm 17.6 & 17.0 \pm 5.9 & 56.8 \pm 19.5\end{array}$

course of the experiment was taken as a covariate in order to filter out different starting conditions. An incomplete model of ANCOVA was used in order to increase the strength of the test. Only interpretable interactions corresponding to the rationale of the experiment were selected. None of the excluded interactions were significant when the full model was used. The Type III sum of squares was used.

Scores on the main PCA axis carried out on the correlation matrix of moisture data in particular plots were taken as another covariate.

\section{RESULTS}

\section{Establishment of plants from rhizome fragments}

Two-way ANOVA revealed significant differences in the number of established rhizome fragments between particular taxa $(F=62.3$, d.f. $=2,102, P<0.001)$. The effect of site (meadow) was also very significant $(F=33.6$, d.f. $=1,102, P<0.001)$, but the interaction of both factors (taxon $\times$ site) was non-significant $(F=0.1$, d.f. $=2,102, P=0.87$ ).

Significantly better establishment was found in $R$. japonica (up to $75 \%$ of regenerated rhizomes, see Tab. 1) and $R$. xbohemica (52.2-65.4\%, depending on the site) than in $R$. sachalinensis, in which the percentage of established rhizomes never exceeded $45 \%$ (Tab. 1). As to the effect of site, plants established themselves better in Site I (Tab. 1).

Repeated planting of the $R$. japonica rhizomes in the two following years made it possible to test for the effect of planting year and site. The effect of site (meadow) on the establishment of rhizome fragments was significant $(F=37.7$, d.f. $=1,68, P<0.001)$ whereas those of the year $(F=3.2$, d.f. $=1,68)$ and the interaction of both (year $\times$ site, $F=1.7$, d.f. $=1,68$ ) were not significant at $\alpha=0.05$.

\section{Effect of meadow management on survival}

Survival in all three Reynoutria taxa was negatively affected by management $(P<0.001$, Tab. 2). Control plants survived better than those exposed to treatments. The differences in survival of control plants and those exposed to management tended to increase during the first two years after planting as indicated by the time $\times$ management interaction which was highly significant $(P<0.001$, Tab. 2). The most severe effect of management was found in 
Table 2. Effects of particular factors (management treatments, site, and time) on the number of surviving plants during the two years after planting in 1996. For each taxon, numbers of plants from 4 sampling dates (i.e. time - analyzed as repeated measures) on 36 plots ( 3 replicates of 6 treatments on 2 experimental meadows) were analyzed. The highest number of living rhizome segments (segment number) recorded during the experiment and the values from the first axis of ordination of soil moisture were used as covariates for each plot (see Methods for details). The following model of ANCOVA was used: Intercept + Covariate-moisture + Covariate-segment number + Taxon + Management + Site + Taxon Management + Taxon $\times$ Site + Management $\times$ Site + Taxon $\times$ Covariate-moisture + Management $\times$ Covariate-moisture + Site $\times$ Covariate-moisture. For the model, only interpretable interactions corresponding to the rationale of the experiment were selected a priori. Effects related to the independent variable "taxon" are shown in capital letters, significant results $(P<0.05)$ related to these factors are displayed in bold.

\begin{tabular}{|c|c|c|c|c|c|c|c|}
\hline Tests of between-subjects effects & d.f. & $F$ & $P$ & Tests of within-subjects contrasts & d.f. & $F$ & $P$ \\
\hline & & & & Time & 1 & 1.7 & 0.199 \\
\hline Covariate-moisture & 1 & 1.0 & 0.311 & time $\times$ covariate-moisture & 1 & 0.0 & 0.985 \\
\hline Covariate-segment number & 1 & 45.2 & $<0.001$ & time $\times$ covariate-segment number & 1 & 21.9 & $<0.001$ \\
\hline TAXON & 2 & 7.3 & 0.001 & TIME $\times$ TAXON & 2 & 6.5 & 0.003 \\
\hline Management & 5 & 102.2 & $<0.001$ & time $\times$ management & 5 & 8.3 & $<0.001$ \\
\hline Site & 1 & 2.8 & 0.101 & time $\times$ site & 1 & 3.8 & 0.058 \\
\hline TAXON $\times$ MANAGEMENT & 10 & 5.9 & $<0.001$ & TIME $\times$ TAXON $\times$ MANAGEMENT & 10 & 2.3 & $\mathbf{0 . 0 2 2}$ \\
\hline TAXON $\times$ SITE & 2 & 3.9 & 0.025 & TIME $\times$ TAXON $\times$ SITE & 2 & 0.2 & 0.815 \\
\hline Management $\times$ site & 5 & 5.3 & $<0.001$ & time $\times$ management $\times$ site & 5 & 1.0 & 0.438 \\
\hline TAXON $\times$ COVARIATE-MOISTURE & 2 & 0.8 & 0.455 & TIME $\times$ TAXON $\times$ COVARIATE-MOISTURE & 2 & 0.2 & 0.826 \\
\hline Management $\times$ covariate-moisture & 5 & 1.5 & 0.214 & time $\times$ management $\times$ covariate-moisture & 5 & 0.6 & 0.699 \\
\hline Site $\times$ covariate-moisture & 1 & 7.1 & 0.010 & time $\times$ site $\times$ covariate-moisture & 1 & 0.5 & 0.469 \\
\hline Error (subject) & 72 & & & Error (time $\times$ subject) & 72 & & \\
\hline
\end{tabular}

$R$. sachalinensis; the majority of plants in treated plots did not survive the first winter (Fig. 2c). The differences in survival between particular management regimes did not show any consistent trends and are difficult to interpret unequivocally (Fig. 2). The effect of site on survival was non-significant (Tab. 2).

Plants in control plots survived best, although their number was decreasing over time. In control plants of all three taxa, there was virtually no mortality during the growing season of either year, and the decrease in the number of surviving plants occurred only during the winter (Fig. 2).

There was a continuing, though less dramatic reduction of the number of survivors in control plots during the following years (Tab. 3). Five years after planting, 12 plants of $R$. japonica (i.e. almost $7 \%$ of the 180 planted in control plots in 1995) still survive in the study sites. Their mean height in 1999 was about $40 \mathrm{~cm}$; the most vigorous plant was $130 \mathrm{~cm}$ tall and had 4 branches and 58 leaves. More than $13 \%$ of $R$. japonica and $12 \%$ of $R$. $\times$ bohemica plants survived for 4 years (from 1996 planting) exhibiting the mean height of about $40 \mathrm{~cm}$ and the maximum height recorded was over $80 \mathrm{~cm}$. In 1999, there were still 5 living plants of $R$. sachalinensis (2.8\%), four of them over $80 \mathrm{~cm}$ tall. The most vigorous plant was $130 \mathrm{~cm}$ tall and had 20 leaves.

\section{Parental taxa and their hybrid: a comparison of response to the treatments}

The data from 1996 trials were used to compare the response of particular taxa of the genus Reynoutria to the treatments applied. If tested by ANCOVA, a significant effect of the independent variable taxon on the survival of plants was revealed $(P=0.001)$ and the same holds for the second-order interactions of taxon with management, time $(P<0.01)$ and site 
a)

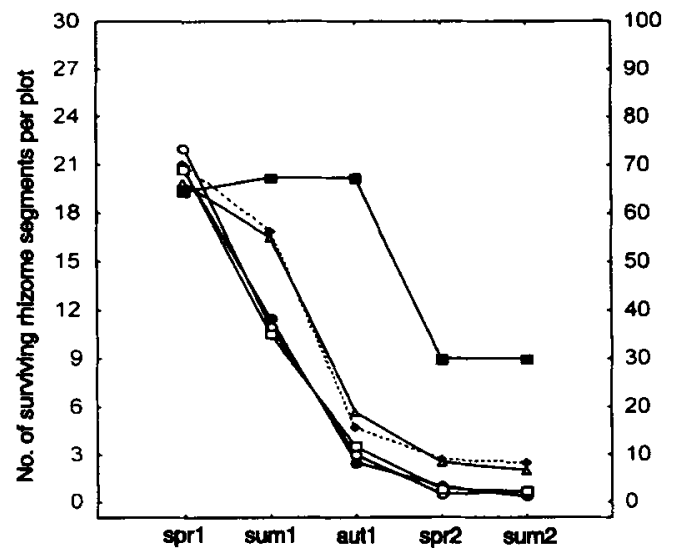

b)

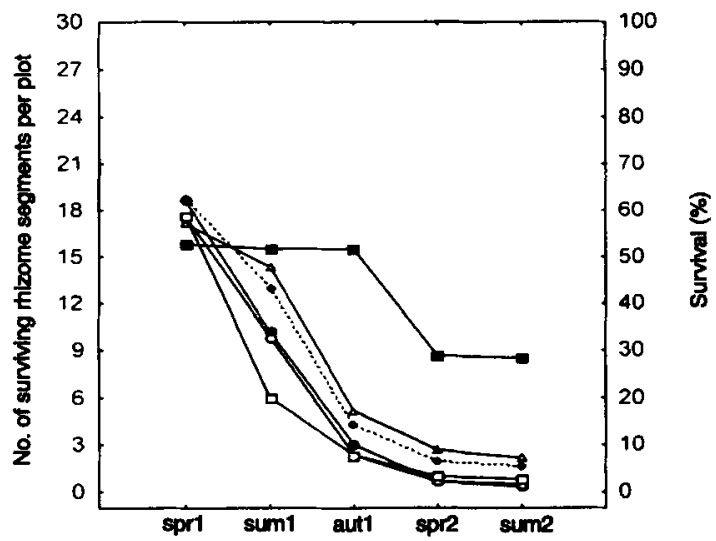

c)
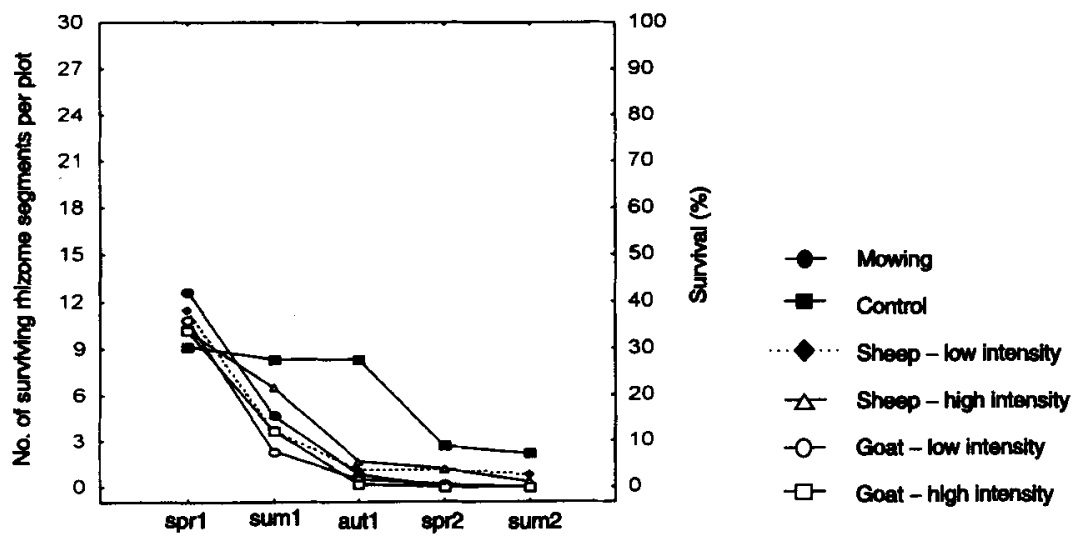

Fig. 2. Survival of Reynoutria plants growing from the established rhizome fragments planted in 1996. Changes in the number of survivors in the two years following the planting are shown as mean values from 6 replicates for each treatment/sampling period. The initial number of rhizome fragments was 30. (a) Reynoutria japonica, (b) $R$. xbohemica, (c) $R$. sachalinensis. Codes: spr - spring, sum - summer, aut - autumn, 1 - Year 1, 2 Year 2. 
Table 3. Number of surviving rhizome fragments of three taxa of Reynoutria in control plots. The records were made at the end of the growing period when plants were best developed. The rhizome fragments bearing at least one living shoot were considered as surviving. Results from both planting years (1995 and 1996) are shown for $R$. japonica. Mean \pm s.d. is shown $(n=6)$. Number of initially planted fragments was 30 per $60 \times 60 \mathrm{~cm}$ plot.

\begin{tabular}{|c|c|c|c|c|c|}
\hline & $\begin{array}{l}\text { R. japonica } \\
\text { (1995) }\end{array}$ & $\begin{array}{l}\text { R. japonica } \\
\quad(1996)\end{array}$ & $\begin{array}{l}\text { R. bohemica } \\
\text { (1996) }\end{array}$ & $\begin{array}{c}\text { R. sachalinensis } \\
\text { (1996) }\end{array}$ & Pooled \\
\hline \multicolumn{6}{|l|}{1995} \\
\hline No. of survived fragments & $24.0 \pm 4.7$ & & & & $24.0 \pm 4.7$ \\
\hline$\%$ & $80.0 \pm 15.6$ & & & & $80.0 \pm 15.6$ \\
\hline \multicolumn{6}{|l|}{1996} \\
\hline No. of survived fragments & $17.3 \pm 5.1$ & $20.2 \pm 5.2$ & $15.5 \pm 5.9$ & $8.3 \pm 3.9$ & $15.3 \pm 6.5$ \\
\hline$\%$ & $57.8 \pm 17.0$ & $67.2 \pm 17.3$ & $51.7 \pm 19.5$ & $27.8 \pm 13.1$ & $51.1 \pm 21.7$ \\
\hline \multicolumn{6}{|l|}{1997} \\
\hline No. of survived fragments & $10.5 \pm 4.3$ & $9.0 \pm 2.7$ & $8.5 \pm 3.3$ & $2.2 \pm 1.8$ & $7.5 \pm 4.4$ \\
\hline$\%$ & $35.0 \pm 14.4$ & $30.0 \pm 8.9$ & $28.3 \pm 10.9$ & $7.2 \pm 6.1$ & $25.1 \pm 14.6$ \\
\hline \multicolumn{6}{|l|}{1998} \\
\hline No. of survived fragments & $3.7 \pm 1.4$ & $6.0 \pm 3.4$ & $4.3 \pm 2.8$ & $1.0 \pm 1.3$ & $3.8 \pm 2.9$ \\
\hline$\%$ & $12.2 \pm 4.6$ & $20.0 \pm 11.4$ & $14.4 \pm 9.3$ & $3.3 \pm 4.2$ & $12.5 \pm 9.6$ \\
\hline \multicolumn{6}{|l|}{1999} \\
\hline No. of survived fragments & $2.0 \pm 1.4$ & $4.0 \pm 2.8$ & $3.7 \pm 3.1$ & $0.8 \pm 1.2$ & $2.6 \pm 2.5$ \\
\hline$\%$ & $6.7 \pm 4.7$ & $13.3 \pm 9.4$ & $12.2 \pm 10.5$ & $2.8 \pm 3.9$ & $8.8 \pm 8.4$ \\
\hline
\end{tabular}

$(P=0.025)$. Of the third-order interactions, that between management $\times \operatorname{taxon} \times$ time was also significant at $P=0.022$ (Tab. 2).

Multiple range comparisons (ANCOVA, Tukey test) revealed that the survival of $R$. japonica and $R$. $\times$ bohemica in the two growing seasons following planting was significantly better than that of $R$. sachalinensis $(P<0.001)$ and the results were consistent in each period (summer 1, autumn 1, spring 2, summer 2).

\section{Between-year comparison of survival in Reynoutria japonica}

The design of the experiment with $R$. japonica (repeated planting in two consecutive growing periods) made it possible to (a) extend the observations on survival over three years and (b) compare the effect of two different years.

In the third year after planting, the survival of control plants followed the same pattern as in the growing period immediately following the start of the experiment. There was no mortality from spring to autumn of Year 2 and at the end of the growing period, $68.8 \pm 14.8 \%$ of plants established in Year 1 had survived. In the winter, a further $29 \%$ died leaving $39.8 \pm 14.1 \%$ surviving from the initial planting (Fig. 3). In treated plots, the significant reducing effect of management was obvious as soon as in the summer of Year 1 (ANCOVA, $F=22.3$, d.f. $=5,22, P<0.001$ ) and the gradual decrease in the number of surviving plants continued throughout the whole observation period (Fig. 3). The maximum number of survivors in the particular treatments at the end of Year 3 was two plants per plot and the differences between treated and control plots were highly significant (Tukey test, $P<0.001$ ). 
a)

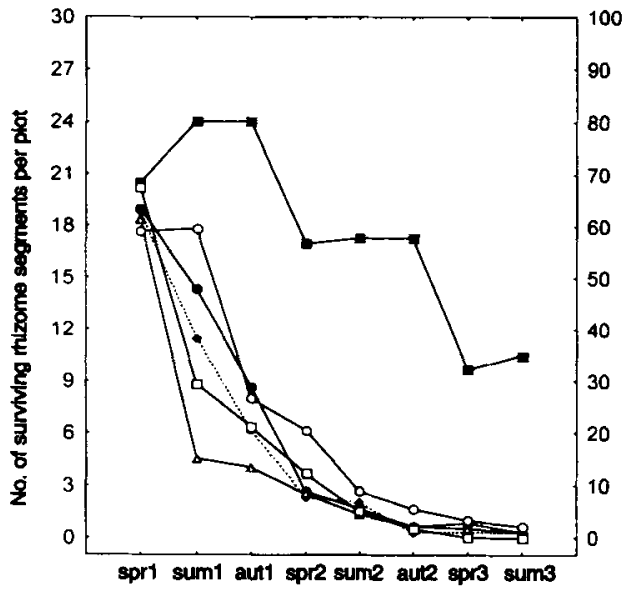

$\frac{8}{5}$

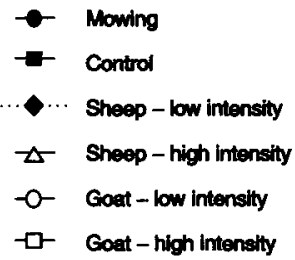

b)
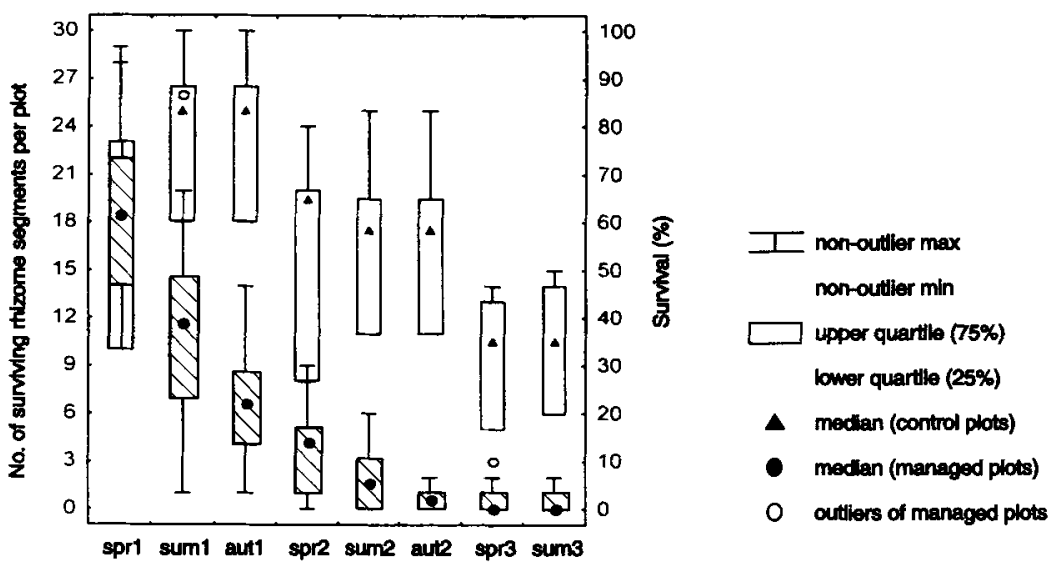

Fig. 3. Changes in the number of surviving rhizome fragments of Reynoutria japonica planted in 1995 over the three years under different treatments. The initial number of rhizome fragments was 30 . (a) Mean values from 6 replicates are shown for each treatment/sampling period. (b) Summary statistics comparing the survival of control plants with pooled data of all the treatments applied as listed in (a). Boxes indicate interquartile ranges; lines surround values that are closer than 1.5 box length from the box; open circles indicate outlying values. Control plots are displayed by using open boxes $(n=6)$, managed plots by solid boxes $(n=30)$. Codes: spr - spring, sum - summer, aut - autumn, 1 - Year 1, 2 - Year 2, 3 - Year 3.

The planting year (1995 vs. 1996) showed a highly significant effect on survival $(P<0.001$, Tab. 4, compare Fig. 2a and 3a). The interactions year $\times$ management, year $\times$ time, and year $\times$ management $\times$ time $\times$ were also highly significant $(P<0.001$, Tab. 4).

\section{DISCUSSION}

Data on regeneration from rhizome fragments under experimental conditions are available for Reynoutria japonica, showing that there is virtually no difference between optimum greenhouse conditions (69\% - BROCK \& WADE 1992) and a field situation represented by mesic meadows observed in the present study $(62.8 \%$ and $68.6 \%$, respectively). The high regeneration potential of knotweeds has been documented not only for rhizomes but also stem 
Table 4. Effects of particular factors (management treatments, site, planting year and time) on the number of surviving plants of Reynoutria japonica planted in two different years (1995 and 1996). For each planting year, numbers of plants from 4 sampling dates (analysed as repeated measures) on 36 plots (3 replicates of 6 treatments on 2 experimental meadows) were analysed. The highest number of living rhizome segments (segment number) recorded during the experiment and the values from the first axis of ordination of soil moisture were used as covariates for each plot (see Methods for details). The following model of ANCOVA was used: Intercept + Covariate-moisture + Covariate-segment number + Taxon + Management + Site + Taxon $\times$ Management + Taxon $\times$ Site + Management $\times$ Site + Taxon $\times$ Covariate-moisture + Management $\times$ Covariate-moisture + Site $\times$ Covariate-moisture. For the model, only interpretable interactions corresponding to the rationale of the experiment were selected a priori. Effects related to the independent variable "year" are shown in capital letters, significant results $(P<0.05)$ related to these factors are displayed in bold.

\begin{tabular}{|c|c|c|c|c|c|c|c|}
\hline Tests of between-subjects effects & d.f. & $F$ & $P$ & Tests of within-subjects contrasts & d.f. & $F$ & $P$ \\
\hline & & & & Time & 1 & 4.4 & 0.042 \\
\hline Covariate-moisture & 1 & 0.6 & 0.456 & time $\times$ covariate-moisture & 1 & 0.3 & 0.570 \\
\hline Covariate-segment number & 1 & 4.3 & 0.044 & time $\times$ covariate-segment number & 1 & 2.6 & 0.112 \\
\hline YEAR & 1 & 16.2 & $<0.001$ & TIME $\times$ YEAR & 1 & 13.2 & 0.001 \\
\hline Mangement & 5 & 64.7 & $<0.001$ & time $\times$ management & 5 & 2.3 & 0.058 \\
\hline Site & 1 & 1.6 & 0.213 & time $\times$ site & 1 & 0.3 & 0.579 \\
\hline YEAR $\times$ MANAGEMENT & 5 & 10.1 & $<0.001$ & TIME $\times$ YEAR $\times$ MANAGEMENT & 5 & 10.4 & $<0.001$ \\
\hline YEAR $\times$ SITE & 1 & 1.7 & 0.195 & TIME $\times$ YEAR $\times$ SITE & 1 & 6.4 & 0.015 \\
\hline Management $\times$ site & 5 & 6.0 & $<0.001$ & time $\times$ management $\times$ site & 5 & 1.6 & 0.179 \\
\hline YEAR $\times$ COVARLATE-MOISTURE & 1 & 0.3 & 0.618 & TIME $\times$ YEAR $\times$ COVARIATE-MOISTURE & 1 & 0.4 & 0.548 \\
\hline Management $\times$ covariate-moisture & 5 & 1.7 & 0.151 & time $\times$ management $\times$ covariate-moisture & 5 & 1.9 & 0.121 \\
\hline Site $\times$ covariate-segment number & 1 & 0.6 & 0.460 & time $\times$ site $\times$ covariate-moisture & 1 & 0.1 & 0.782 \\
\hline Error (subject) & 44 & & & Error (time $\times$ subject) & 44 & & \\
\hline
\end{tabular}

fragments (BROCK et al. 1995) and establishment from fallen leaves has even been observed (BRABEC 1997).

Both $R$. japonica and the hybrid $R$. xbohemica established and survived better than $R$. sachalinensis in both treated and control plots. In the control plots, subsequent mortality of all three taxa occurred almost exclusively during winter, reducing the number of surviving shoots to about a half. This may correspond to the fact that $R$. japonica is vulnerable to late frosts (BEERLING et al. 1994). About one third (of the original number of planted segments, i.e. 30) $R$. japonica $(30.0 \pm 10.3 \%)$ and $R$. xbohemica $(28.9 \pm 12.9 \%)$ plants successfully survived the first winter in the 1996 experiment and the figure was even higher $(56.7 \pm 20.4 \%)$ in the $R$. japonica experiment in 1995 . Even after $4-5$ years after planting, there were 5-24 plants (depending on taxon and planting year) surviving in the control plots and some of them were growing rather vigorously. It seems highly probable that, had they been given a chance, they would have established invasive populations. This holds true namely for $R$. japonica and $R$. xbohemica; $R$. sachalinensis was less successful.

The highly significant effect of year on the survival of $R$. japonica plants found in the present study indicates that specific conditions may have a remarkable effect on the outcome of an invasion. We are not aware of any environmental factor such as climate or disturbance which could be used to explain this difference in our study.

We are aware of some limitations to the comparison between taxa resulting from the fact that each taxon was represented by rhizomes sampled from a single clone. This is irrelevant in the case of $R$. japonica, as its genetic diversity is extremely limited in the study area (PYŠEK \& MANDÁK, unpubl. data). BAILEY et al. (1995) reported on extremely low genetic diversity in $R$. japonica and supposed that all plants in the United Kingdom belonged to the same 
genotype. Available evidence about genetic variation in $R$. sachalinensis is scarce (BAILEY et al. 1995, HOLLINGSWORTH et al. 1998). It seems, therefore, that the invasion superiority, in terms of establishment and early phase of invasion, of $R$. japonica over its congener $R$. sachalinensis, has a general validity in Central European situations. In the case of $R$. xbohemica probably exhibiting the highest genetic variation of the three (HOLLINGSWORTH 1998, PYŠEK \& MANDÁK, unpubl. data) the results must be interpreted with caution because of the limited, in genetic terms, material used for the experiment. However, ongoing research indicates that $R$. $\times$ bohemica has, under experimental conditions taking genetic variation into account, the highest regeneration potential of the three congeners (BÍMOVÁ, PYŠEK \& MANDÁK, unpubl. data). Differences in the ecological behaviour of closely related species have been reported (KRAHULEC et al. 1999, STÖCKLIN 1999, HROUDOVÁ et al. 1999) and recent analyses have found that hybrids may possess lower, equivalent or higher levels of fitness relative to their parental taxa (ARNOLD \& HoDGES 1995).

In the present study, the high intensity grazing was achieved in a different way than under traditional management. For technical reasons, more grazers acting for shorter times were used. Nevertheless, we believe that the effect of simulated grazing was very similar to the real effect of traditional grazing. The present study proved that grazing is an effective means to prevent the invasion of Reynoutria species into meadow communities. This statement seems, however, only valid if grazing is applied in the early phase of invasion. BEERLING et al. (1994) also reported on the negative effect of grazing on $R$. japonica but still the species is fairly common in pastures (BEERLING 1991, BEERLING \& PALMER 1994). It appears that, once established, the clones cannot be efficiently eliminated by grazing. The effect of mowing on large established stands is also unequivocal since it is sometimes considered as an inefficient means of control, even triggering resprouting (BEERLING et al. 1994) while other studies reported on clones effectively controlled (DE WAAL 1995). The results of application of any control measure heavily depend on the respective situation, i.e. the size and age of the clone, frequency of application and the way in which the measures are used, and the ecological condition of the site. The differences found in establishment rates between both sites considered in the present study indicate that the initial phase of the invasion process can be principally affected by relatively subtle differences in the characteristics of recipient habitats. As demonstrated by the experiment with $R$. japonica replicated in the two subsequent years, the effect of the particular year may also play a role.

On the basis of our results, it can be concluded that if traditional management is applied continuously, it represents an effective barrier to the establishment of knotweed populations. However, once interrupted or ceased, the potential for invasion increases and if it occurs, special control measures are required to eliminate the invading plants effectively.

It is necessary to point out that the present experiment used relatively small segments of rhizomes but in the wild, bigger fragments are probably also spread. BROCK \& WADE (1992) showed that the regeneration rate increases with fragment size; new viable plants established from $40 \%$ of segments which were $1 \mathrm{~cm}$ long, but the corresponding figure for $8 \mathrm{~cm}$ segments was $93 \%$. In the real situation, the invasive potential of the taxa studied is probably even higher.

Acknowledgements: Our thanks are due to Tomáš Herben for advice on statistics and helpful comments, František Krahulec and two anonymous referees for comments on the previous versions of the manuscript and Jan Suda for assistance with counting the chromosome numbers. Petra Nová kindly drew the management factors displayed in Fig. 1. Lois Child is acknowledged for improving our English. We thank the inhabitants 
of the Brejl settlement, namely Ms Suchopárková, her family and Vašek Somol, for logistic support, friendly environment, loan of animals and valuable advice on agricultural management. The work was supported by grant no. 204/93/2440 and partly by no. 206/99/1239 from the Grant Agency of the Czech Republic.

\section{REFERENCES}

ARNOLD M.L. \& HODGES S.A. (1995): Are natural hybrids fit or unfit relative to their parents? Trends Ecol. Evol. 10: 67-71.

BAILEY J.P. (1990): Breeding behaviour and seed production in alien Giant Knotweed in the British Isles. In: PALMER J. (ed.), The biology and control of invasive plants, Industr. Group. British Ecol. Soc., Cardiff, pp. 110-120.

BAILEY J.P., CHILD L.E. \& WADE M. (1995): Assessment of the genetics variation of British populations of Fallopia japonica and its hybrid Fallopia xbohemica. In: PYŠEK P., PRACH K., REJMÁNEK M. \& WADE M. (eds.), Plant invasions: general aspects and special problems, SPB Academic Publishing, Amsterdam, pp. 141-150.

BALEY J.P. \& STACE C.A. (1992): Chromosome number, morphology, pairing, and DNA values of species and hybrids in the genus Fallopia (Polygonaceae). Pl. Syst. Evol. 180: 29-52.

BASTL M., KOČ́́R P., PRACH K. \& PYŠEK P. (1997): The effect of successional age and disturbance on the establishment of alien plants in man-made sites: an experimental approach. In: BROCK J.H., WADE M., PYŠEK P. \& GREEN D. (eds.), Plant invasions: Studies from North America and Europe, Backhuys Publishers, Leiden, pp. 191-201.

BEERLING D.J. (1991): The effect of riparian land use on the occurrence and abundance of Japanese knotweed (Reynoutria japonica) on selected rivers in South Wales. Biol. Conservation 55: 329-337.

BEeRling D.J., BAILeY J.P. \& CONOLly A.P. (1994): Fallopia japonica (HouTT.) RonSE DE CRAENE (Reynoutria japonica HoUTT.; Polygonum cuspidatum SIEB. \& ZUCC.). J. Ecol. 82: 959-979.

BEERLING D.J., HUNTLEY B. \& BAILEY J.P. (1995): Climate and the distribution of Fallopia japonica: use of an introduced species to test the predictive capacity of response surface. J. Veg. Sci. 6: 269-282.

BEERLING D.J. \& PALMER J.P. (1994): Status of Fallopia japonica (Japanese knotweed) in Wales. In: DE WAAL L.C., CHILD E.L., WADE P.M. \& BROCK J.H. (eds.), Ecology and management of invasive riverside plants, John Wiley \& Sons, Chichester, pp. 199-211.

BRABEC J. (1997): Experimentální studie vlivu obhospodařování na invazi vybraných druhů do lučních porostů (Experimental study of the effect of management on invasion of selected plants species into meadow communities). Thesis, Charles University, Praha.

BROCK J.H. (1994): Technical note: standing crop of Reynoutria japonica in the autumn of 1991 in the United Kingdom. Preslia 66: 337-343.

BROCK J.H. \& WADE M. (1992): Regeneration of Japanes knotweed (Fallopia japonica) from rhizome and stems: Observation from greenhouse trials. In: IXème Colloque International sur la biologie des mauvaises herbes, Dijon, pp. 85-94.

BROCK J.H., CHILD L.E., DE WAAL L.C. \& WADE P.M. (1995): The invasive nature of Fallopia japonica is enhanced by vegetative regeneration from stem tissues. In: PYŠEK P., PRACH K., REJMÁNEK M. \& WADE M. (eds.), Plant invasions: general aspects and special problems, SPB Academic Publishing, Amsterdam, pp. 131-139.

CHRTEK J. (1990): Fallopia, Reynoutria. In: HeJNÝ S. \& SLAVÍk B. (eds.), Kvètena České republiky (Flora of the Czech Republic) 2, Academia, Praha, pp. 359-366.

CRAWLEY M.J. (1987): What makes a community invasible? In: GRAY A.J., CRAWLEY M.J. \& EDWARDS P.J. (eds.), Colonization, succession and stability, Blackwell Scientific Publications, Oxford, pp. 429-453.

DE WAAL L. (1995): Treatment of Fallopia japonica near water: a case study. In: PYŠEK P., PRACH K., REJMÁNEK M. \& WADE M. (eds.), Plant invasions: general aspects and special problems, SPB Academic Publishing, Amsterdam, pp. 203-212.

DE WAAL L.C., CHILD E.L., WADE P.M. \& BROCK J.H. (eds.) (1994): Ecology and management of invasive riverside plants, John Wiley \& Sons, Chichester.

HOBBS R.J. (1989): The nature and effects of disturbance relative to invasions. In: DRAKE J.A., MOONEY H.A., DI CASTRI F., GROVES R.H., KRUGER F.J., REJMÁNEK M. \& WILlIAMSON M. (eds.), Biological invasions: a global perspective, John Wiley \& Sons, Chichester, pp. 389-405. 
HoBBS R.J. \& HUENNEKE L.F. (1992): Disturbance, diversity and invasion: implication for conservation. Conservation Biol. 6: 324-337.

HoBBS R.J. \& HUMPHRIES S.E. (1995): An integrated approach to the ecology and management of plant invasion. Conservation Biol. 9: 761-770.

HollingsworTh M.L., HOLlingsworTH P.M., JENKINS G.I. \& BaILeY J.P. (1998): The use of molecular markers to study patterns of genotypic diversity in some invasive alien Fallopia spp. (Polygonaceae). Molec. Ecol. 7: 1681-1691.

HORN P. \& PRACH K. (1995): Aerial biomass of Reynoutria japonica and its comparison with that of native species. Preslia 66 (1994): 345-348.

HROUDOVÁ Z., ZÁKRAVSKÝ P. \& FRANTíK T. (1999): Ecological differentiation of Central European Bolboschoenus taxa and their relationship to plant communities. Folia Geobot. 34: 77-96.

HURLBERT S.H. (1984): Pseudoreplication and the design of ecological field experiments. Ecol. Monogr. 54: $187-211$.

JALAS J. \& SUOMINEN J. (eds.) (1988): Atlas florae europae: distribution of vascular plants in Europe 4, The Committee for Mapping the Flora of Europe and Societas Biologica Fennica Vanamo, Helsinki.

KOWARIK I. (1995): On the role of alien species in urban flora and vegetation. In: PYŠEK P., PRACH K., REJMÁNEK M. \& WADE M. (eds.), Plant invasions: general aspects and special problems, SPB Academic Publishing, Amsterdam, pp. 85-103.

KRAHULEC F., MARHOLD K. \& SCHMID B. (1999): Ecology of closely related plant species: an introduction. Folia Geobot. 34: 1-5.

MANDÁK B. \& PYŠEK P. (1997): Druhy rodu Reynoutria na území České republiky (Species of the genus Reynoutria at the territory of the Czech Republic). In: PYŠEK P. \& PRACH K. (eds.), Invazní rostliny v České flóře (Invasive plants in the Czech flora), Zprávy České Bot. Společn. 32, Mater. 14: 45-57.

MARIGO G. \& PAUTOU G. (1998): Phenology, growth and ecophysiological characteristics of Fallopia sachalinensis. J. Veg. Sci. 9: 379-386.

NEUHÄUSLOVÁ $Z$. et al. (1998): Map of the potential natural vegetation of the Czech Republic. Academia, Praha.

PYŠEK P. \& PRACH K. (1993): Plant invasion and role of riparian habitats: a comparison of four alien to Central Europe. J. Biogeogr. 20: 413-420.

PYŠEK P. \& PRACH K. (1994): How important are rivers for supporting plant invasions? In: DE WAAL L.C., CHILD L.E., WADE P.M. \& BROCK J.H. (eds.), Ecology and management of invasive riverside plants, John Wiley \& Sons, Chichester, pp. 19-26.

PYŠEK P., PRACH K. \& MANDÁK B. (1998): Invasions of alien plants into habitats of Central European landscape: an historical pattern. In: STARFINGER U., EDWARDS K., KOWARIK I. \& WILLIAMSON M. (eds.), Plant invasions: ecological mechanisms and human responses, Backhuys Publishers, Leiden, pp. 23-32.

PYŠEK P. \& PYŠEK A. (1995): Invasion by Heracleum mantegazzianum in different habitats in the Czech Republic. J. Veg. Sci. 6: 711-718.

REJMÁNEK M. (1989): Invasibility of plant communities. In: DRAKE J.A., MOONEY H.A., DI CASTRI F., GROVES R.H., KRUGER F.J., REJMÁNEK M. \& WILLIAMSON M. (eds.), Biological invasions: a global perspective, John Wiley \& Sons, Chichester, pp. 369-388.

SALISBURY E.J. (1961): Weeds and aliens. Collins, London.

SCHWABE A. \& KRATOCHWIL A. (1991): Gewässer-begleitende Neophyten und ihre Beurteilung aus Naturschutz-Sicht unter besondere Berücksichtigung Südwestdeutschlands. Norddeutsche Naturschutzakad. Ber. 4(1): 14-27.

SEIGER L.A. (1997): The status of Fallopia japonica (Reynoutria japonica; Polygonum cuspidatum) in North America. In: BROCK J.H., WADE M., PYŠEK P. \& GREEN D. (eds.), Plant invasions: Studies from North America and Europe, Backhuys Publishers, Leiden, pp. 95-102.

STÖCKLIN J. (1999): Differences in life history traits of related Epilobium species: clonality, seed size and seed number. Folia Geobot. 34: 7-18.

SUKOPP H. \& STARFINGER U. (1995): Reynoutria sachalinensis in Europe and in the Far East: A comparison of the species ecology in its native and adventive distribution range. In: PYŠEK P., PRACH K., REJMÁNEK \& WADE M. (eds.), Plant invasions: general aspects and special problems, SPB Academic Publishing, Amsterdam, pp. 151-159.

SUKOPP H. \& SUKOPP U. (1988): Reynoutria japonica HOUTT. in Japan und in Europa. Veröff. Geobot. Inst. ETH Stiftung Rübel Zürich 98: 354-372. 
TADE ZoKU K. (1965): Polygonum. In: OHWI J. (ed.), Flora of Japan, Smithsonian Institute, Washington, pp. $405-413$.

THÉBAUD C. \& DEBUSSCHE M. (1991): Rapid invasion of Fraxinus ornus L. along the Herault River system in southem France: the importance of seed dispersal by water. J. Biogeogr. 18: 7-12.

USHER M.B. (1988): Biological invasions of nature reserves: a search for generalisation. Biol. Conservation 44: 119-135.

VitouseK P. M., Walker L.R., Whitaker L.D., Mueller-Dombois D. \& MATSON P.A. (1987): Biological invasion by Myrica faya alters ecosystem development in Hawaii. Science 238: 802-804.

WILliamson M. (1996): Biological invasions. Chapman \& Hall, London.

Received 11 November 1999, revision received 10 February 2000, accepted 24 February 2000 